Thermodynamics in Geology 
NATO A DVANCEDSTUDY INSTITUTES SERIES

Proceedings of the Advanced Study Institute Programme, which aims at the dissemination of advanced knowledge and the formation of contacts among scientists from different countries

The series is published by an international board of publishers in conjunction with NATO Scientific Affairs Division
A Life Sciences
Plenum Publishing Corporation
B Physics
London and New York
Mathematical and
Physical Sciences
D. Reidel Publishing Company
Dordrecht and Boston
Behavioral and
Social Sciences
Sijthoff International Publishing Company Leiden
E Applied Sciences
Noordhoff International Publishing
Leiden

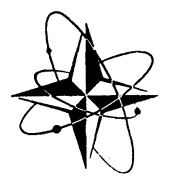

Series C - Mathematical and Physical Sciences

Volume 30 - Thermodynamics in Geology 


\section{Thermodynamics \\ in Geology}

Proceedings of the NATO Advanced Study Institute

held in Oxford, England, September 17-27, 1976

edited by

DONALD G. FRASER

Dept. of Geology and Mineralogy, University of Oxford, England

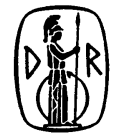

\section{Reidel Publishing Company}

Dordrecht-Holland / Boston-U.S.A.

Published in cooperation with NATO Scientific Affairs Division 


\section{Library of Congress Cataloging in Publication Data}

Nato Advanced Study Institute, Oxford, 1976.

Thermodynamics in geology.

(NATO advanced study institutes series : Series C, Mathematical and physical sciences ; v. 30)

Bibliography: $p$.

Includes index.

1. Geology--Congresses. 2. Thermodynamics-Congresses. I. Fraser, Donald G., 1949- II. Title. III. Series. QE509.N37 1976 551 $77-3242$

ISBN-13: 978-90-277-0834-2 e-ISBN-13: 978-94-010-1252-2

DOI: 10.1007/978-94-010-1252-2

Published by D. Reidel Publishing Company P.O. Box 17, Dordrecht, Holland

Sold and distributed in the U.S.A., Canada, and Mexico by D. Reidel Publishing Company, Inc.

Lincoln Building, 160 Old Derby Street, Hingham, Mass. 02043, U.S.A.

\section{All Rights Reserved}

Copyright (C) 1977 by D. Reidel Publishing Company, Dordrecht, Holland

Softcover reprint of the hardcover Ist edition 1977

No part of the material protected by this copyright notice may be reproduced or utilized in any form or by any means, electronic or mechanical, including photocopying, recording or by any informational storage and retrieval system, without written permission from the copyright owner 
TABLE OF CONTENTS

Preface

1. GEOLOGICAL APPLICATIONS OF HIGH TEMPERATURE REACTION CALORIMETRY

A. Navrotsky, Arizona State University

1.1 Introduction

1.2 Calorimetric solvents and oxide melts

1.3 Applications of high temperature calorimetry to mineral thermodynamics

1.4 Calorimetry of geothermal fluids and water containing systems at pressures up to $2 \mathrm{kbar}$

Study Problems

2. EXPERIMENTAL DETERMINATION OF THE MIXING PROPERTIES OF SOLID SOLUTIONS WITH PARTICULAR REFERENCE TO GARNET AND CLINOPYROXENE SOLUTIONS

B.J. Wood, University of Manchester

2.1 Introduction

2.2 $\mathrm{NaAlSi}_{3} \mathrm{O}_{8}-\mathrm{KAlSi}_{3} \mathrm{O}_{8}$ feldspar solutions

$2.3 \mathrm{MgSi}_{0.5} \mathrm{O}_{2}-\mathrm{FeSi}_{0.5 \mathrm{O}_{2}}$ olivine solutions

2.4 Aluminosilicate garnet solid solutions

2.5 Clinopyroxenes containing $\mathrm{CaAl}_{2} \mathrm{SiO}_{6}$ component

2.6 Conclusions

3. THERMOCHEMISTRY OF GARNETS AND ALUMINOUS PYROXENES

IN THE CMAS SYSTEM

R.C. Newton, University of Chicago

3.1 Importance of the CMAS system

3.2 Experimental difficulties

3.3 The role of thermochemistry

$3.4 \mathrm{CaMgSi}_{2} \mathrm{O}_{6}-\mathrm{CaAl}_{2} \mathrm{SiO}_{6}$ clinopyroxene 32

$3.5 \mathrm{Mg}_{3} \mathrm{~A}_{2} \mathrm{Si}_{3} \mathrm{O}_{12}-\mathrm{Ca}_{3} \mathrm{Al}_{2} \mathrm{Si}_{3} \mathrm{O}_{12}$ garnet 37

3.6 Application to the garnet peridotite problem 40

Study Problems 
4. ACTIVITY-COMPOSITION RELATIONSHIPS FOR CRYSTALLINE SOLUTIONS

R. Powe11, University of Leeds

4.1 Introduction

4.2 Mole fractions

4.3 Activity coefficients

4.4 Conclusions

64

5. CHEMICAL MIXING IN MULTICOMPONENT SOLUTIONS:

AN INTRODUCTION TO THE USE OF MARGULES AND OTHER THERMODYNAMIC EXCESS FUNCTIONS TO REPRESENT NON-IDEAL BEHAVIOUR

J. Grover, University of Cincinnati

5.1 Introduction

5.2 The solution properties of a binary mixture

5.3 Ternary and higher order chemical mixtures

5.4 Representation of the excess Gibbs free energy of mixing

5.5 The Margules equations

5.6 An annotated list of geological publications utilizing the Margules equations or their equivalents

Study Problems

6. DETERMINATION OF ATOMIC OCCUPANCIES

E.J.W. Whittaker, University of Oxford

6.1 Introduction

$\begin{array}{lll}6.2 & \text { The diffraction method } & 100 \\ 6.3 \text { Mössbauer spectroscopy } & 106\end{array}$

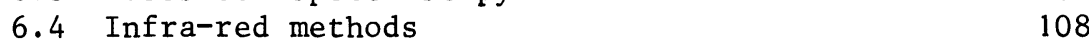

6.5 The meaning of occupancy 109

Study Problem

111

Solution to Problem

7. THE ACCURACY AND PRECISION OF CALCULATED MINERAL DEHYDRATION EQUILIBRIA

G.M. Anderson, University of Toronto

7.1 Introduction

7.2 Definitions

7.3 Accuracy of calculated equilibria

7.4 Precision of calculated equilibria

7.5 Thermochemical data from P-T brackets 127

$\begin{array}{ll}7.6 \text { Discussion and conclusions } & 129\end{array}$

Study Problems 
8. THERMODYNAMICS OF DEHYDRATION EQUILIBRIA

N.D. Chatterjee, Ruhr University, Bochum

8.1 Introduction

8.2 Theoretica1 background

8.3 Retrieval of thermodynamic data

8.4 Calculation of phase diagrams

8.5 Dehydration equilibria involving crystalline. solutions

Study Problems

Solutions to Problems

9. FUGACITY AND ACTIVITY OF MOLECULAR SPECIES IN SUPERCRITICAL FLUIDS

J.R. Holloway, Arizona State University

9.1 Introduction

9.2 Scope and definitions

9.3 Review of available experimental data

9.4 Molecular dynamics

9.5 The Redlich-Kwong equation of state

172

9.6 Conclusions

179

Study Problems

180

10. COMPOSITIONS AND THERMODYNAMICS OF METAMORPHIC SOLUTIONS

H.P. Eugster, Johns Hopkins University

10.1 Introduction

$10.20-\mathrm{H}$ gases

$10.3 \mathrm{C}-0$ gases

$10.4 \mathrm{C}-\mathrm{O}-\mathrm{H}$ gases

$10.5 \mathrm{C}-\mathrm{O}-\mathrm{H}-\mathrm{S}$ gases

$10.6 \mathrm{H}-\mathrm{O}-\mathrm{F}$ and $\mathrm{H}-\mathrm{O}-\mathrm{N}$ gases

10.7 Acids and bases

10.8 Measurement of the activity of $\mathrm{H}_{2} \mathrm{O}$

10.9 Summary and conclusions

Study Problems

202

11. THE SIGNIFICANCE OF FLUID INCLUSIONS IN METAMORPHIC ROCKS

J. Touret, University of Paris

11.1 Introduction

11.2 Observation by conventional techniques (petrographic microscopy)

11.3 Microthermometry: $\mathrm{T}_{f}$ and $\mathrm{T}_{\mathrm{h}}$

11.4 Other analytical methods

11.5 Conclusion 
12. THE STABILITY OF PHLOGOPITE IN THE PRESENCE OF QUARTZ AND DIOPSIDE

D.R. Wones and F.C.W. Dodge, U.S. Geol. Survey

12.1 Introduction

12.2 Experimental methods

12.3 Stability of phlogopite and quartz

232

12.4 Stability of phlogopite quartz and diopside

240

12.5 Thermodynamic considerations

240

12.6 Geological applications

243

Study Problems

13. OPAQUE MINERALS AS SENSITIVE OXYGEN BAROMETERS AND GEOTHERMOMETERS IN LUNAR BASALTS

A. E1 Goresy, Heidelberg, Max-P1anck-Institut and E. Woermann, Aachen, Institut für Krista1lographie

13.1 Introduction

13.2 Spinel solid solution series

13.3 Armalcolite series

257

13.4 Subsolidus. reduction reactions

260

14. THERMODYNAMIC: PROPERTIES OF MOLTEN SALT SOLUTIONS $0 . J . K 1$ eppa, University of Chicago

14.1. Introduction

14.2 Systems of the type AX-BX

14.3 Systems of the type AX-AY

14.4 Charge unsymmetrical mixtures which contain a common anion

14.5 Mixtures containing two cations and two anions 295

15. THERMODYNAMIC PROPERTIES OF SILICATE MELTS

D.G. Fraser, University of Oxford

15.1 Introduction

15.2 Nature of silicate melts 303

$\begin{array}{ll}15.3 \text { Acids and bases } & 306\end{array}$

$\begin{array}{ll}15.4 \text { Binary silicate melts } & 307\end{array}$

$\begin{array}{ll}15.5 \text { Application of mixing models } & 312\end{array}$

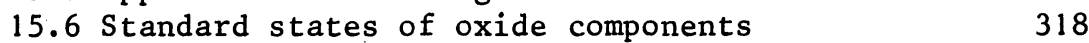

15.7 Effects of melt structure on liquidus boundaries 
16. THE ACTIVITIES OF COMPONENTS IN NATURAL SILICATE MELTS

J. Nicholls, University of Calgary

16.1 Introduction

16.2 Thermodynamic characterization of silicate melts 328

16.3 Estimation of pressures and temperatures of equilibration

332

16.4 Example and discussion

339

Appendix: Program for solving equations for $\mathrm{P}$ and $\mathrm{T} 343$ Study problem

348

17. THE THERMODYNAMICS OF TRACE ELEMENT DISTRIBUTION

R.K. O'Nions, Columbia University and

R. Powel1, University of Leeds

17.1 Introduction

17.2 Henry's Law

17.3 Formulation of distribution coefficients

17.4 Relationship between distribution coefficients and equilibrium constants

17.5 Geothermometry and geobarometry

17.6 Trace elements in gas-solid reactions

17.7 Concluding Remarks

362

18. THE SOLUBILITY OF CALCITE IN SEA WATER

W.S. Broecker and T. Takahashi,

Columbia University

18.1 Introduction

365

18.2 In situ saturometry

369

18.3 Laboratory kinetic measurements

372

18.4 Possible explanations for the differences between the Berner and Ingle et al. solubility results

18.5 Conclusions

19. NONEQUILIBRIUM THERMODYNAMICS IN METAMORPHISM

381

G.W. Fisher, John Hopkins University

19.1 Introduction

381

19.2 Fundamental relations

19.3 Models for diffusion-controlled, steady-state processes

19.4 The transformation to practical reference frames

394

19.5 App1ication to the Vastervik segregations 396

19.6 Conclusion

400

Study Problems

401

Solutions to Problems

402 
PREFACE

It has long been realized that the mineral assemblages of igneous and metamorphic rocks may reflect the approach of a rock to chemical equilibrium during its formation. However progress in the application of chemical thermodynamics to geological systems has been hindered since the time of Bowen and the other early physical-chemical petrologists by the recurring quandary of the experimental geologist. His systems are complex and are experimentally intractable, but if they were not so refractory they would not be there to study at all. It is only recently that accurate measurements of the thermodynamic properties of pure, or at least well-defined minerals, melts and volatile fluid phases, combined with experimental and theoretical studies of their mixing properties, have made it possible to calculate the equilibrium conditions for particular rock systems.

Much work is now in progress to extend the ranges of composition and conditions for which sufficient data exist to enable such calculations to be made. Moreover the routine availability of the electron microprobe will ensure that the demand for such information will continue to increase.

The thermodynamic techniques required to apply these data to geological problems are intrinsically simple and merely involve the combination of appropriate standard state data together with corrections for the effects of solution in natural minerals, melts or volatile fluids. However the vocabulary of the subject often appears foreign to geologists and there has been a lack of up-todate text books available for use in courses on thermodynamics in geology. The N.A.T.O. Advanced Study Institute, of which this volume is the Proceedings, set out to review some of the progress which has been made in the field, and to survey some topics of current research. In particular, however, the Institute functioned as a teaching medium in which the various review lecturers supplemented their talks with study problems worked out during afternoon teaching sessions. 
The volume "Thermodynamics in Geology" is therefore more than just the proceedings of a conference, since each review lecturer was asked to write a chapter suitable for use as a teaching text. The book begins with a chapter on calorimetry (Navrotsky) followed by two chapters on the experimental determination of activitycomposition relationships of mineral solid solutions by phase equilibrium experiments (Wood) and by high temperature solution calorimetry (Newton). After chapters on the nature of activitycomposition relationships (Powell) and the expression of non-ideal behaviour using Margules' equations (Grover), a review of experimental techniques available for determining site occupancy is given (Whittaker).

The extraction of thermodynamic data from phase diagrams together with an analysis of accuracy and precision is considered by Anderson and Chatterjee and this section is followed by a discussion of the properties of volatile phases. The properties of supercritical solutions are reviewed by Holloway, and this is followed by a chapter on metamorphic solutions by Eugster and a review of studies of fluid inclusions is given by Touret.

Two specific examples of the application of thermodynamic methods to geological problems are considered by Wones and Dodge (biotites as monitors of granitic melts) and by El Goresy and Woermann (opaque minerals as oxygen barometers and geothermometers). These are followed by a section on the thermodynamic properties of melts. Following a review of the properties of "simple" molten salts (Kleppa) the nature and properties of silicate melts are considered by Fraser. This is followed by a chapter by Nicholls on the treatment of activities in natural silicate melts and a discussion of trace element behaviour by O'Nions and Powell.

Finally the kinetics of carbonate dissolution in sea-water are considered (Broecker and Takahashi) and a review of non-equilibrium thermodynamics in petrology is given by Fisher.

That so many authors should co-operate in this way to produce the collection of chapters in this volume, many provided with study problems and worked solutions, is a tribute to the enthusiasm and good-will of all those who participated in the Institute. We all hope that those reading the book will find it both useful and enjoyable. 
ACKNOWLEDGEMENTS

The chapters in this volume were written by the review lecturers at the NATO Advanced Study Institute held in the Department of Geology and Mineralogy, University of Oxford from 17th - 27th September 1976. I should like to thank all the lecturers for their care in preparing both their lectures and the review chapters and study problems presented here.

The Institute itself grew out of a number of one week vacation courses for British graduate students held in the Department of Geology, University of Manchester. These courses were organized and run by Drs. R.K. O'Nions, R. Powell, B.J. Wood and myself and I gratefully acknowledge their contributions which made the Institute possible. I particularly wish to thank Bernie Wood for his good advice on numerous occasions. I also thank the Natural Environment Research Council for financial support of the courses.

The Institute could not have been held without the good-will and co-operation of the technical and academic staff of the Department of Geology, University of Oxford and I thank them all for their assistance before, during and after the Institute. I particularly thank Valerie Miles for handling all the correspondence, Peter Deussen for help with draughting and design, and our conference secretary, Dominique, for her charm, good humour and cheerful efficiency.

Finally, I should like to thank my wife, Anna, both for her help and for her forbearance, and Pat Jackson for her skill in producing camera-ready typescript to a tight schedule.

All the members of the Institute thank NATO for its generous financial support.

$$
\text { D.G.F. }
$$

